\title{
DESIGNING AN IMPACT ENERGY-ABSORBING DEVICE: NUMERICAL SIMULATIONS
}

\begin{abstract}
The numerical results of 1100-aluminium extrusion tests conducted at a tool velocity of $36 \mathrm{~km} / \mathrm{h}$ are presented. Engineering applications of the considered problem concern the use of this extrusion technology in the design of an impact energyabsorbing device. Viscous and plastic properties of the extruded materials are described on the basis of numerical simulations of a tensile test in which the BodnerPartom material model is applied. The numerical results are compared with experimental ones.
\end{abstract}

Keywords: 1100 aluminium, Bodner-Partom, extrusion

\section{Introduction}

Competition and intensification in industrial production require the development of new materials with the required mechanical properties. Enhancements in forming processes, as well as the search for new unconventional uses of this technology, have prompted the need for the correct description of the behaviour of metallic materials at very high strain rates, often up to $5000 \mathrm{~s}^{-1}$. In order to fully control the process of plastic deformation, the influence of strain rate on the mechanics of plastic flow (yield stress, strain heterogeneity, etc.) should be investigated [1]. However, at present, the possibility of testing and determining the characteristics of materials under high strain rates is limited by the availability of research equipment, the ambiguity of the applied methods and procedures, and the complexity of the phenomena of deformation. As a result, engineers and researchers typically do not possess all relevant information regarding the behaviour of materials under high strain rates [2]. A certain ability to describe material behaviour under high strain rates can be obtained by the application of mathematical models such as the Bodner-Partom [3], Zerilli-Armstrong [4] and Johnson-Cook [5]. However, the application of these models is associated with

\footnotetext{
${ }^{1}$ Autor do korespondencji/corresponding author: Grażyna Ryzińska, Rzeszow University of Technology, 8 Powstańców Warszawy Ave., 35-959 Rzeszów, Poland, tel.: +4817 865 1507, email: grar@prz.edu.pl

2 Andrzej Skrzat, Rzeszow University of Technology, e-mail: askrzat@prz.edu.pl
} 
certain assumptions and limitations, including the need to derive the coefficients and constants for each material model, which is usually not straightforward [6].

The numerical results of 1100 aluminium extrusion at $36 \mathrm{~km} / \mathrm{h}$ tool speeds that impose large strain rates in the extruded material are presented in this paper. Detailed experimental investigation of the mechanical behaviour of 1100 aluminium at different strain rates was made previously by Huang and Khan [7], who used their experimental data to derive the material parameters for the Bodner-Partom material model. The parameters obtained by Huang and Khan are used in the present study for the numerical simulation of a simple tension test, with the aim of obtaining pseudo-experimental stress-strain curves of 1100 aluminium at different (high) strain rates. As an example of a practical engineering application, the extrusion technology employed in designing impact energyabsorbing devices is considered. Devices of this type must comply with certain requirements that mainly represent constant force versus displacement of the piston, and objective absorbed energy amount. An exemplary dependence of force versus displacement for an impact energy-absorbing device required by the manufacturer is shown in Fig. 1. Numerical simulations of the extrusion process obtained via the use of commercial FEM software are ill-conditioned and highly non-linear due to the existence of large displacements and large strains, material nonlinearities and contacts. Very large deformations of the extruded material require continuous remeshing or involve the application of a Eulerian approach [8] in which the finite element mesh remains stationary and material flows through it. In the presented investigations the Lagrangian approach enhanced by a remeshing technique is used, with the material data obtained from the results of tension test simulations of the Bodner-Partom material model.

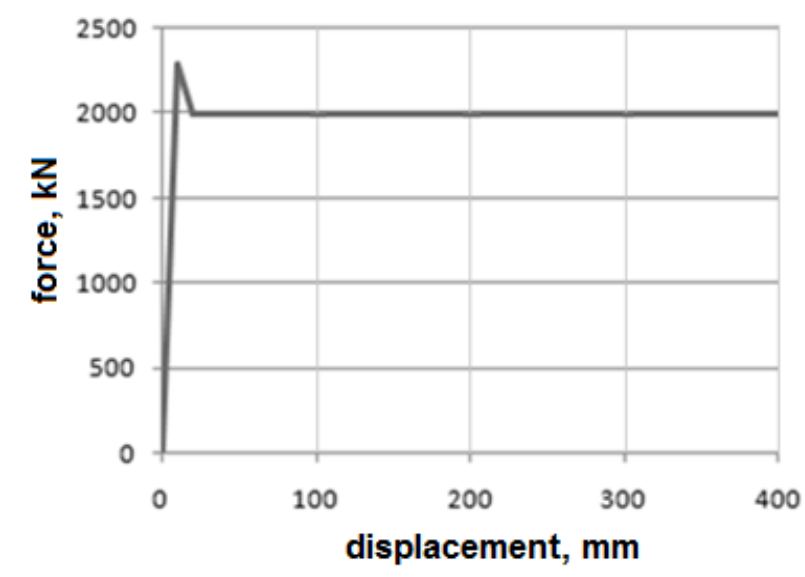

Fig. 1. Exemplary dependence of the force versus displacement for an impact energy-absorbing device 


\section{Bodner-Partom material model}

There are several material models available that represent the elastic viscoplastic properties of bodies subjected to large strains at high strain rates and temperatures. The application of these material models requires knowledge of material data that sometimes must be chosen arbitrarily, e.g. the description and parameters of back stress in visco-plastic problems. In order to avoid the selection of an inappropriate material model and material data not suitable for solving the extrusion problem at high strain rates, the well-known Bodner-Partom material model based on the unified theory of plasticity is used here. The BodnerPartom material model (1975) is formulated as the set of constitutive equations representing elastic visco-plastic strain-hardening material behaviour for large deformations and arbitrary loading. An essential feature of this formulation is that total deformation consists of both elastic and inelastic components, which are functions of the material parameters and state variables at all stages of loading and unloading. The Bodner-Partom material model thus allows the simultaneous consideration of elastic and plastic effects, isotropic and kinematic hardening, visco-plasticity, creep and relaxation for a wide temperature range. The Bodner-Partom material model is defined by the following equations:

- superposition of elastic and inelastic strains:

$$
\varepsilon_{i j}=\varepsilon_{i j}^{(e)}+\varepsilon_{i j}^{(i e)}
$$

- incompressibility condition for inelastic deformations:

$$
\varepsilon_{k k}^{(i e)}=0
$$

- plastic flow law:

$$
\dot{\varepsilon}_{i j}^{(i e)}=\lambda s_{i j}
$$

where: $S_{\mathrm{ij}}$ is deviatoric stress and the plastic multiplier is:

$$
\lambda=\sqrt{\frac{D_{0}^{2}}{J_{2}} \exp \left(-\left(\frac{Z^{2}}{3 J_{2}}\right)^{n}\right)}
$$

In (4), $D_{0}$ and $n$ are B-P material constants and $J_{2}$ is the second invariant of deviatoric stress. The state variable $Z=Z^{I}+Z^{D}$ represents the resistance of the material to inelastic deformations - both isotropic $Z^{I}$ and directional $Z^{D}$. The evolution of $Z^{I}$ is defined as:

$$
\dot{Z}^{I}=m_{1}\left(Z_{1}-Z^{I}\right) \sigma_{i j} \dot{\varepsilon}_{i j}^{(i e)}-A_{1} Z_{1}\left(\frac{Z^{I}-Z_{2}}{Z_{1}}\right)^{r 1}
$$


Parameter $Z^{D}$ depends on tensorial quantity $\beta_{i j}$

$$
Z^{D}=\beta_{i j} \frac{\sigma_{i j}}{\left\|\beta_{i j}\right\|}
$$

where:

$$
\dot{\beta}_{i j}=m_{2}\left(Z_{3} \frac{\sigma_{i j}}{\left\|\sigma_{i j}\right\|}-\beta_{i j}\right) \sigma_{i j} \dot{\varepsilon}_{i j}^{(i e)}-A_{2} Z_{1}\left(\frac{\left.\left\|\beta_{i j}\right\|\right)^{r 2}}{Z_{1}}\right)^{\frac{\beta_{i j}}{\left\|\beta_{i j}\right\|}}
$$

where: $m_{1}, m_{2}, A_{1}, A_{2}, Z_{1}, Z_{2}, Z_{3}, r_{1}, r_{2}$ are B-P material constants described below.

For the inelastic strain rate derived from (3), the elastic stress rate is determined from the generalised Hooke's law:

$$
\dot{\sigma}_{i j}^{(e)}=C_{i j k l}\left(\dot{\varepsilon}_{k l}-\dot{\varepsilon}_{k l}^{(i e)}\right)
$$

Bodner-Partom material parameters are described below:

E - elastic modulus,

$v$ - Poisson's ratio,

$\mathrm{D}_{0}$ - limiting shear-strain rate,

$\mathrm{Z}_{0}$ - initial value of isotropic hardening variable,

$\mathrm{Z}_{1}$ - limiting value for isotropic hardening,

$Z_{2}$ - fully recovered value (isotropic hardening),

$\mathrm{Z}_{3}$ - limiting value for kinematic hardening,

$\mathrm{m}_{1}$ - hardening rate coefficient (isotropic),

$\mathrm{m}_{2}$ - hardening rate coefficient (kinematic),

$\mathrm{n}$ - strain rate sensitivity parameter,

$A_{1}$ - recovery coefficient for isotropic hardening,

$\mathrm{A}_{2}$ - recovery coefficient for kinematic hardening,

$\mathrm{r}_{1}$ - recovery exponent (isotropic hardening),

$\mathrm{r}_{2}$ - recovery exponent (kinematic hardening).

An appropriate numerical program based on equations (1)-(8) was developed to predict material response for 1D loading and unloading, applying the explicit integration procedure. All derivatives in Eqs. (1)-(8) are replaced by finite differences. Huang and Khan [7] proposed the following magnitudes: $D_{0}=$ $108 \mathrm{~s}^{-1}, n=0.87, m=0.2193, Z_{0}=552 \mathrm{MPa}, Z_{1}=1026.84 \mathrm{MPa}$. Their model does not consider either isotropic or kinematic hardening, which for simple loading process (no unloading and no cycling loading) can be neglected. 


\section{Numerical simulations}

The 1100 aluminium used in the numerical calculations provides very low strain hardening. Selected properties of this 1100 aluminium material include the following: yield stress - $105 \mathrm{MPa}$, ultimate strength - $110 \mathrm{MPa}$, density - 2.7 $\mathrm{g} / \mathrm{cm}^{3}$.

On the basis of the Bodner-Partom constitutive equations, a numerical program was developed which allows for the discrete generation of stress-strain curves for simple tension tests at various strain rates. Selected numerically generated stress-strain curves for the Bodner-Partom material model (Fig. 2) were used later as material characteristics for 1100 aluminium in Lagrangian simulations of the extrusion process. Characteristics of the same material were previously obtained experimentally by Huang and Khan (Fig. 3), who proved in several tests [7] a good correlation between experimental and numerical (BodnerPartom material model) data. The main advantage of such numerically generated data is that the stress-strain relation can be obtained for an arbitrary strain rate, whereas in experimental studies only a few strain rates can be investigated.

Fig. 2. Stress-strain curves for various strain rates: Numerical simulation of tensile tests using the Bodner-Partom material model

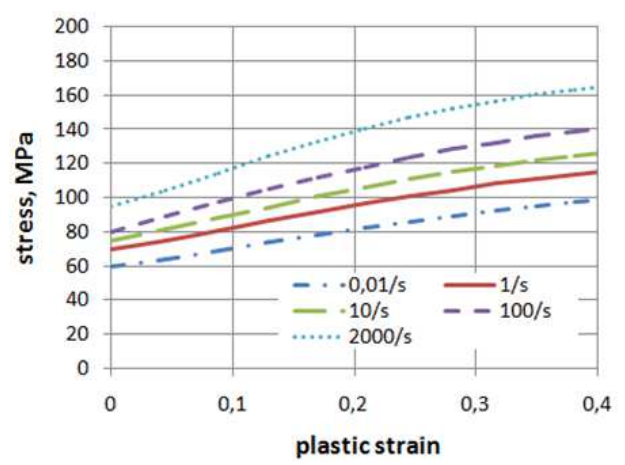

Fig. 3. Stress-strain curves for various strain rates: Experimental data (elaborated based on [7])

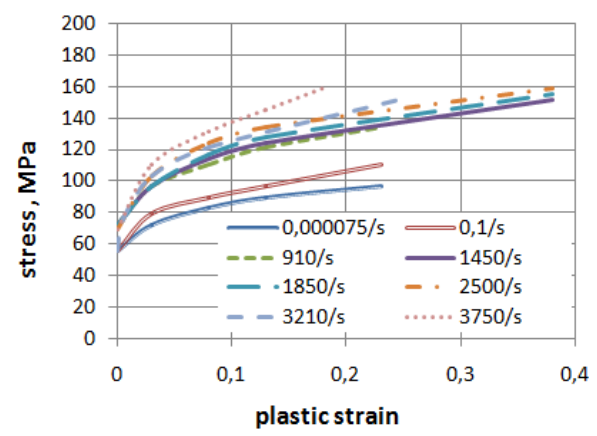

As part of the presented research, many numerical simulations of 1100 aluminium extrusion were conducted using the Simufact.forming software program [8]. Experimental stress-strain characteristics based on literature data [7] 
were introduced, as well as material data generated by a procedure based on the Bodner-Partom model. The dimensions of the impact energy-absorbing device were initially estimated for an expected force of $2000 \mathrm{kN} \pm 10 \%$ (absorbed energy $E=1 \mathrm{MJ} \pm 10 \%$ ), with the load applied as the mass velocity of $10 \mathrm{~m} / \mathrm{s}$ or as the total energy absorbed. The results of simulations using the material data obtained from experimental investigations and numerically generated data were then compared. Table 1 presents the details of the FEM model.

In the model, the extrusion problem is solved as an explicit dynamic analysis in which highly non-linear effects are considered. Material deformation is forced by a single blow of the hammer. A suitable design of the punch geometry (extrusion ratio $\lambda$ ) enabled the determination of the expected magnitude of the extrusion force, which is consistent with forces acting in real vehicle collision tests, as well as the appropriate level of absorbed energy. The problem is solved via axisymmetric analysis. A general view of the analysed object is shown in Fig. 4.

Table 1. Details of the FEM model

\begin{tabular}{|l|l|}
\hline Feature & Description \\
\hline Model geometry & Axisymmetric \\
\hline Approach & updated Lagrangian \\
\hline Friction & Bilinear (Coulomb 0.05; Tresca 0.08) \\
\hline Temperature & $293.15 \mathrm{~K}$ \\
\hline Initial tool velocity & $10 \mathrm{~m} / \mathrm{s}$ \\
\hline Mass of tool & $20 \mathrm{~T}$ \\
\hline Expected absorbed energy E & $2000 \mathrm{kN}$ \\
\hline Number of elements & 2384 \\
\hline Remeshing & Continuous \\
\hline Integration procedure & Explicit \\
\hline Yield criterion & Huber-Misess \\
\hline Flow rule & Prandtl-Reuss \\
\hline
\end{tabular}

a)

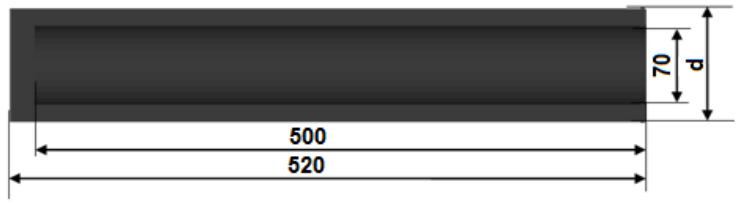

b)
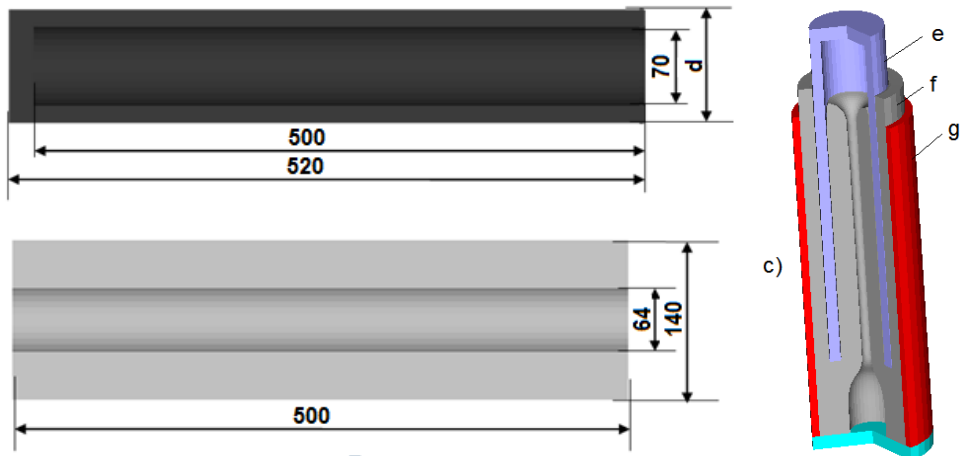

Fig. 4. Geometric parameters of the impact energy absorbing device: a) punch, b) ingot, c) general view (e -punch, $f$ - ingot, $g$ - container $)\left(d_{1}=100 ; d_{2}=102 ; d_{3}=104\right)$ 


\section{Results and conclusions}

Selected results of the extrusion simulations carried out using the Simufact.forming program are presented below. In Fig. 5 a plot of punch force in terms of punch displacement is presented. The extrusion force obtained for the Bodner-Partom material is insignificantly larger than the force provided by calculations based on experimental data. Figure 6 presents the variation of punch velocity with time. While punch velocity decreases from $10000 \mathrm{~mm} / \mathrm{s}$ to zero, the total energy increases, as shown in Fig. 7.

The present research encountered an interesting problem associated with the extrusion of 1100 aluminium. The main goal of this study was to estimate initial parameters of the impact energy-absorbing device that satisfy manufacturer requirements (constant force, the amount of absorbed energy etc.). Although the constant force criterion can be satisfied by the application of the backward extrusion process, the main problem encountered during numerical calculations is the selection of an appropriate material model that assumes elastic visco-plastic properties. The properties of 1100 aluminium used in the designed energyabsorbing device were taken from experimental investigations conducted by Huang and Khan, with the same researchers providing material parameters for the Bodner-Partom material model. These parameters were used by the latter authors in a numerical program simulating a simple tension test performed for various strain rates. In this way, stress-strain characteristics can be obtained.

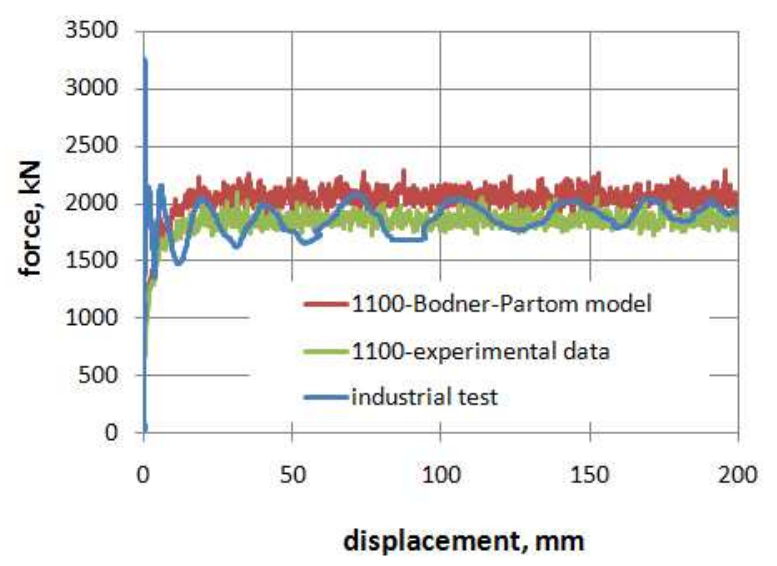

Fig. 5. Comparison of impact energy-absorbing device real test results with the results of numerical simulations

A comparison of the numerical computations (force displacement dependence) carried out for the proposed device based on the Bodner-Partom material model and experimental data reveals small differences in the magnitude of the 
punch force, although the force-displacement relation remains the same for both material data.

The main requirement regarding the amount of absorbed energy is satisfied, while the numerical simulations demonstrate that the constant force criterion is better satisfied in the proposed device than in the existing device (see Fig. 5). The application of the Bodner-Partom material model in calculations of 1100 aluminium extrusion at high strain rates produced a good correlation with the experimental tests. FEM analysis of backward extrusion further enabled the optimisation of the parameters of the designed energy-absorbing device.

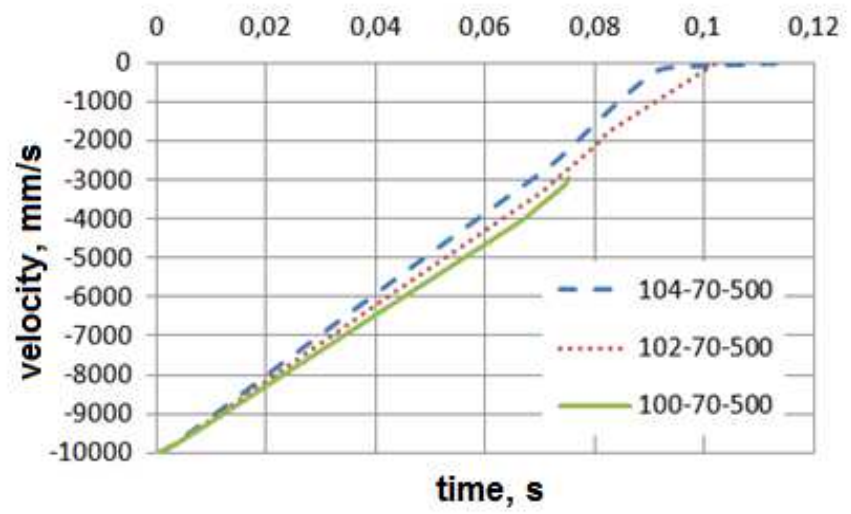

Fig. 6. Relationship between punch velocity and time for 1100 aluminium

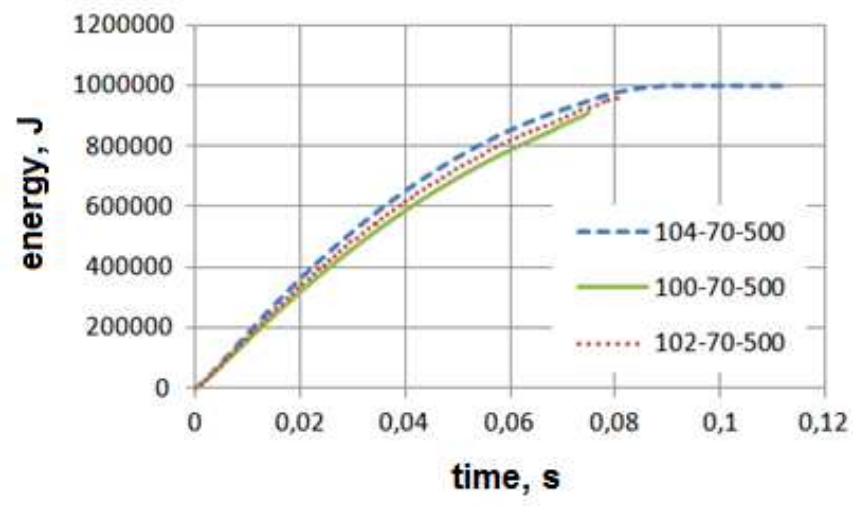

Fig.7. Relationship between total energy and time for 1100 aluminium

\section{References}

[1] Klepaczko J.R., Chiem G.C.Y.: On rate sensitivity of FCC metals, instantaneous rate sensitivity and rate sensitivity of strain hardening, Journal of Mechanics and Physics of Solids, vol. 34, 1986, pp. 29-54. 
[2] Malinowski J., Kowalewski Z., Kruszka L.: Doświadczalna metoda oraz badania plastycznego płynięcia metali w zakresie bardzo wysokich prędkości odkształcenia, IFTR Reports IPPT PAN, vol.10, 2007, pp. 1-88.

[3] Bodner S.R., Partom Y.: Constitutive equations for elastic-viscoplastic strainhardening materials, Journal of Applied Mechanics, vol. 42, 1975, pp. 385-389.

[4] Zerilli F.J., Armstrong R.W.: Dislocation-mechanics-based constitutive relations for material dynamics calculations, Journal of Applied Physics, vol. 61, 1987, pp. 1816-1825.

[5] Johnson G.R., Cook W.H.: A constitutive model and data for metals subjected to large strains, high strain rates and high temperatures, In: 7th Int. Symposium on Ballistics, Hague, 1983, pp. 541-547.

[6] Skrzat A.: Fuzzy logic application to stress-strain analysis in selected elastic-plastic material models, Archives of Metallurgy and Materials, vol. 56, 2011, pp.559-568.

[7] Huang S., Khan A.S.: Modelling the mechanical behaviour of 1100-0 aluminium at different strain rates by the Bodner-Partom model, International Journal of Plasticity, vol. 8, 1992 pp. 501-517.

[8] http://www.simufact.com/simufact-products.html

\section{PROJEKTOWANIE URZĄDZEŃ POCHŁANIAJĄCYCH ENERGIE UDERZENIA - SYMULACJE NUMERYCZNE}

\section{Streszczenie}

W pracy zaprezentowano wyniki obliczeń numerycznych wyciskania przeciwbieżnego aluminium w gatunku $1100 \mathrm{z}$ prędkością $36 \mathrm{~km} / \mathrm{h}$. Elementy technologii wyciskania zastosowano do projektowania urządzeń pochłaniających energię uderzenia. Właściwości lepko-plastyczne materiału zostały opisane $\mathrm{w}$ oparciu o symulację numeryczną testu jednoosiowego rozciągania z zastosowaniem modelu Bodnera-Partoma. Wyniki symulacji numerycznej porównano z wynikami eksperymentalnymi.

Słowa kluczowe: aluminium 1100, Bodner-Partom, wyciskanie

DOI: $10.7862 / \mathrm{rm} .2015 .34$

Otrzymano/received: $12.09 .2015 \mathrm{r}$.

Zaakceptowano/accepted: 23.11.2015 r. 